\title{
レーザー捕そく・顕微分光法による単一微粒子の 分光分析
}

\author{
金 幸 夫 $^{\circledR * *}$ ，中谷 清治 ${ }^{* *}$ ，八尾 浩史 ${ }^{* *}$, 喜多村 曻 ${ }^{* *}$
}

(1995 年 7 月 21 日受付)

\begin{abstract}
マイクロメートルサイズの微粒子を非接触・非破壊に自由に操ることのできるレーザー捕そく法と, 空間分解能を持つ顕微分光法を組み合わせたレーザー捕そく・顕微分光法を用いることにより，微粒子 1 粒ごとの分光分析が可能である.これを用い，水中に分散した油滴の油水界面で起こる反応の解析， 油滴の融合, マイクロカプセル調製時に生じる内包物質の不均一 (濃度) 分布, イオン交換過程の直接 測定に応用した例について紹介する. 微粒子 1 粒ごとの分光分析を行い，その粒径依存性を検討する ことにより，従来の分散系や微粒子集合系の測定では知り得なかった粒ごとの濃度の違いや微粒子内で の分布状態を明らかにすることができる．空間配置を意識した測定・反応の重要性についても合わせて 述べる.
\end{abstract}

\section{1 緒言}

溶液中に固体微粒子や微小液滴なざを分散させた微粒 子分散系は, クロマトグラフィーや液-液抽出といった 分析手法としてのみならず, 我々の身の回りのいたると ころで様々な形で利用されている。これらの微粒子分散 系では, 固-液あるいは液-液界面自体の特徴だけではな く, 界面を通しての溶質の物質移動, 拡散 (浸透), 分 配, 反応過程が重要であり, その微視的過程の本質的理 解が必要不可欠である.

界面の関与する現象が化学にとって非常に重要である ことは言うまでもない，通常のバルク二層界面に関して は, 近年発達してきた種々の分光法や電気化学的手法 (例えば，全反射分光法，界面 SHG 測定，液-液界面を 経由するイオン透過電流の測定等) などを駆使して，活 発に議論されている ${ }^{1) ~ 5)}$. 一方, 微粒子分散系におい ては, 界面の関与する現象は界面の性質だけではなく, 粒子サイズによっても影響される。すすわち，微粒子の 粒径が小さくなると, その体積に比べ表面積が増大する ために界面の寄与が相対的に大きくなる. 従って, 界面 がかかわる現象を微粒子 1 粒ごとに測定し, 微粒子の 粒径に対する依存性を調べることによって，これまでと

* 関東支部創立 40 周年記念

** 北海道大学大学院理学研究科化学専攻: 060 北海道 札幌市北区北 10 条西 8 丁目
は異なった視点からの情報を得ることができるものと期 待される.

微粒子のかかわる現象は種々の方法により調べられて いるが, 微粒子 1 粒ごとに着目した研究は限られてい る. 例えば，分子・イオンの吸着過程を検討する場合, 一般的には吸着剤を調べるのではなく, 溶液中の濃度減 少をもとに議論がなされるか6 ${ }^{6) ~}$, 拡散反射分光法な ぞを用い吸着剤 1 粒ではなくその集合体の測定がなさ れる ${ }^{910)}$. 又, 液-液抽出においては, 実際には液滴 1 粒ごとの液-液界面を通して物質移動が起こっているに もかかわらず, 静置し完全に分離した後の二層の濃度が 調べられるのが一般的である ${ }^{6)}$ ，吸着郕や液滴の大きさ は決して単分散ではなく粒径分布を持っている．先にも 述べたように，粒径の異なる微粒子では異なる挙動をと ることが予想されるにもかかわらず，これまでの研究に おいては粒径分布を統計的に仮定してしまうか，粒子ご との特性を無視して解析する等が主流であったため, 「平均值の化学」と言わざるを得ない11) 13).

実際に，微粒子 1 粒ごとの分析を行い，その粒径依 存性を調べるためには,

1）微粒子を非破壊・非接触で自由にマニピュレート する方法

2）微小試料に適用可能な高感度分析法

3） 1 粒だけを測定するための空間分解能を有する分 析法 
を確立する必要がある．著者らは光の放射圧を利用して 微粒子を自由に操ることができるレーザー捕そく法, 及 び高感度かつ空間分解能を有する測定法としての顕微分 光法を組み合わせ, 微粒子 1 粒ごとの分光測定が可能 であることを報告してきた ${ }^{14) 15)}$ 。このレーザー捕そ く・顕微分光法を更に発展させ，マイクロメートルサイ ズの微小領域で起こる現象とその特徵を明らかにするこ とを試みている ${ }^{16)}$. 本論文では, レーザー捕そく・顕 微分光法について簡単に述べた後, 水中に分散させた油 滴, マイクロカプセル, 及び固体吸着剤としてのイオン 交換樹脂を対象とした研究例について紹介する.

\section{2 レーザー捕そく・顕微分光システム}

\section{$2 \cdot 1$ レーザー捕そく法}

照射波長において透明なマイクロメートルサイズの球 形微粒子にレーザー光を照射する場合を考え，レーザー 捕そくの基本原理を述べる(Fig. 1) ${ }^{14) 15)}$. 光が媒体か ら微粒子に入射するとき，その界面で屈折が起こり進行 方向が変化する．この屈折により光の運動量は変化する が $(\Delta P)$, 運動量保存則により微粒子に反作用力が㗢く $(-\Delta P)$. 微粒子の中を通過した光は媒質へ出るときに 再び屈折し，微粒子に力を及ぼす。これらの微粒子に働 く力（光の放射圧）は非常に弱く, 通常, 我々はその力 を意識することはないが，対物レンズで集光されたレー ザー光を照射した場合には，微粒子にとって十分大きな 力となる ${ }^{17)}$.

微粒子の屈折率 $\left(n_{1}\right)$ が周りの媒体の屈折率 $\left(n_{2}\right)$ よ りも高いとき $\left(n_{1}>n_{2}\right.$, 例えば, 水中のポリマー微粒 子), 様々な角度から入射した光による放射圧の合力を 計算すると, 光の焦点方向を向く力となる $(F)$. 放射 圧 $F$ の大きさは，微粒子の表面付近にレーザー光の焦 点がきたときを最大にして，それょり遠ざかると減少し ていく. 従って, レーザー光の光路に近づいた微粒子 は，放射圧により光の焦点方向に引き込まれ，焦点近傍 で三次元的に捕そく・固定される．このとき，微粒子の マクロな運動が抑えられるだけではなく，そのブラウン 運動も抑えられるため, 顕微鏡観察では, 微粒子は完全 に静止している，一度捕そくされた微粒子は，捕そく用 レーザーを動かしてもその動きに追随し常にレーザー光 の焦点にくるため, 微粒子を任意の空間で, 非破壊・非 接触的にマニピュレートすることができる．この方法 は, 光ピンセットとも呼ばれ, 特に細胞をマニピュレー 卜する方法として近年, 注目されている ${ }^{18)}$.

一方，微粒子の屈折率が低い場合には（有機溶媒中の 水滴), 放射圧は微粒子をレーザー光の焦点からはじき

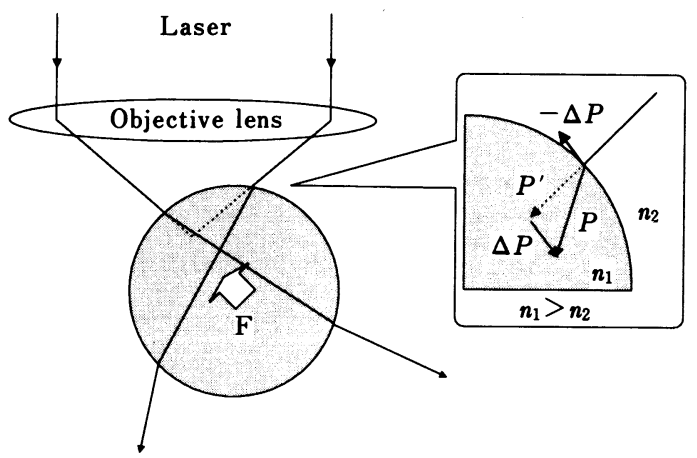

Fig. 1 Principle of laser trapping

The refractive index of a particle $\left(n_{1}\right)$ is larger than that of the surrounding medium $\left(n_{2}\right)$.

Focused laser beam

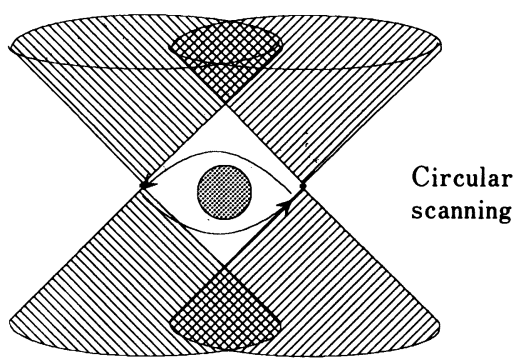

Fig. 2 Principle of laser-scanning manipulation $\left(n_{1}<n_{2}\right)$

飛ばす方向に働くため先の方法では捕そくすることがで きない，このような場合，レーザー走査法により微粒子 をマニピュレートできることが報告されている(19). Fig. 2 に示すように, コンピュータ制御されたガルバノミ ラーを用いて，レーザー光を微粒子の周囲を高速に円形 走查する. 走查速度が微粒子のブラウン運動よりも速け れば，微粒子はレーザー光によりすべての方向から反発 力を受けるために “光のかご”に閉じ込められる．その 結果, 微粒子は走査レーザーの中心に捕そく・固定され る.このレーザー走查マニピュレーション法によれば, 球形ではなく不規則な形状をした微粒子であっても， レーザー光をその形状にあわせて走査することにより捕 そくできることも報告されている14)15).

更に，複数の捕そく用レーザーを用いることにより， 同時, かつ独立に複数の微粒子を捕そく・固定し, 自由 
にマニピュレートすることも可能である. 複数の微粒子 を任意に操ることにより, それらの距離や配置を自由に 制御するとともに，異なる液滴を接触・融合させること も可能である.

\section{$2 \cdot 2$ 吸収・発光スペクトル測定}

著者らが用いているレーザー捕そく・顕微分光システ ムのブロックダイアグラムを Fig. 3 に示す. 捕そく用 のレーザー光としては, 連続波 Nd: YAG レーザーの 基本波（顕微鏡下で数十 $\mathrm{mW}$ 程度）を用いている.こ の捕そく用レーザー光と同軸で， $1 \mu \mathrm{m}$ 程度に絞った測 定光を試料に照射することにより，任意の微粒子 1 粒 の分光測定が可能となる. つまり, 微粒子は捕そく用 レーザー光の焦点位置に固定されているため, 測定光は 必ず微粒子の中心を通る. 球形の微粒子を測定対象とす る場合, スペクトル強度, 及び形状を再現性よく測定す るためにはレーザー捕そくは必要不可欠である20).

吸収測定の場合, 図に示すように Xe ランプからの白 色光をハーフミラーにより顕微鏡内に導入し, 試料を透 過した光を顕微鏡下部より取り出す. 又, 発光測定の場 合には，励起光をダイクロイックミラーを用いて顕微鏡 に導入し, 試料からの発光を対物レンズで集光した後 に, 顕微鏡上部から検出器へ導く. 検出器にはゲート動 作可能なマルチチャンネル型光検出器を用い, 瞬時に $250 \mathrm{~nm}$ の波長範囲のスペクトルを, $5 \mathrm{~ns}$ の時間分解能 で測定できる. あるいは, 高感度二次元電荷結合素子 （CCD）カメラを用いることにより画像情報（透過光強 度又は発光強度の空間分布）も得ることができる. 更 に, 基板上にマイクロ電極を設置することにより, 分光 測定と同時に電気化学測定も可能である16)21).

\section{$2 \cdot 3$ 三次元空間分解発光測定}

顕微吸収測定においては試料を透過した光を測定する ために, 光軸 $(z$ 軸) 方向の空間分解能はない. 又, 発 光測定においても, 通常の顕微鏡では励起光の焦点から の発光だけではなく, 励起光が通過するすべての点から の発光を検出してしまうため, 三次元空間分解能は得ら れない. しかし, 励起光の入射部と発光の出射部（検出 器の前) に光学的にマッチングしたピンホールを設置し た共焦点型顕微鏡を用いることにより, 励起光の焦点か らのみの発光を検出することができる (Fig. 4) ${ }^{22)}$. す なわち, ピンホールを通過した励起光は対物レンズを通 して試料に照射される. この励起光の焦点からの発光は (実線), 再び同一の対物レンズにより集光され検出器の 前のピンホール上に結像し検出器に導入される. 励起光

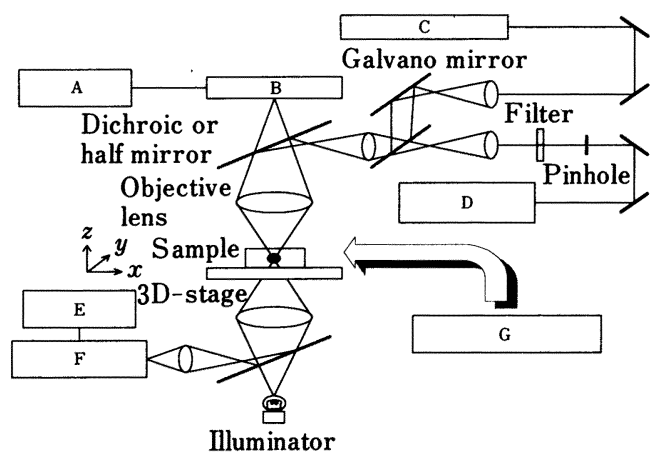

Fig. 3 Block diagram of a laser trapping-microspectroscopy system

A: Monitor; B: CCD camera; C: cwNd: YAG laser; D: Xe lamp or pulsed laser; E: computer; F : multichannel photodetector; G: electrochemical analyzer

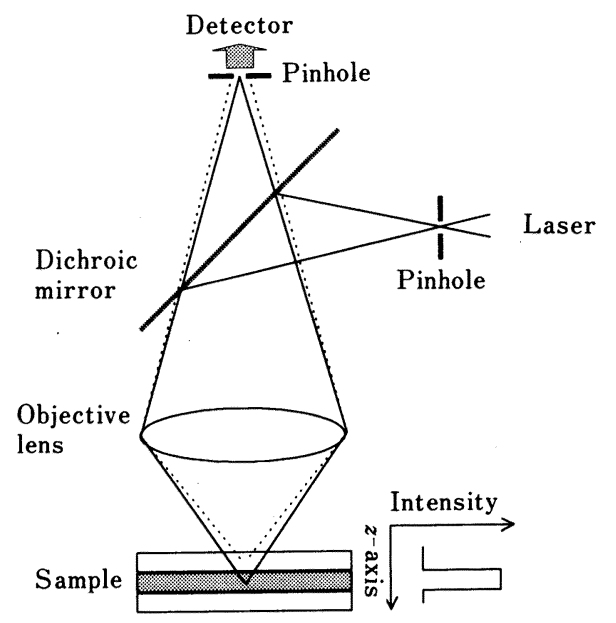

Fig. 4 Optical system of a confocal fluorescence microscope

の焦点位置以外からの発光は (破線), 検出器の前のピ ンホール上には結像せず, ほとんどの光はカットされ検 出されない. その結果, 励起光の焦点位置からのみの発 光だけを検出することができる. 試料ステージを上下. 左右に移動させることにより, 励起光の焦点を $x y z$ 軸方 向に走査し, 各焦点位置からの発光を測定することを通 して, 三次元空間分解発光测定が可能となる.

$2 \cdot 2$ で述べた方法により, 微粒子 1 粒の分光測定が可 能となり, 更に, 共焦点顕微鏡を用いることにより, 微 


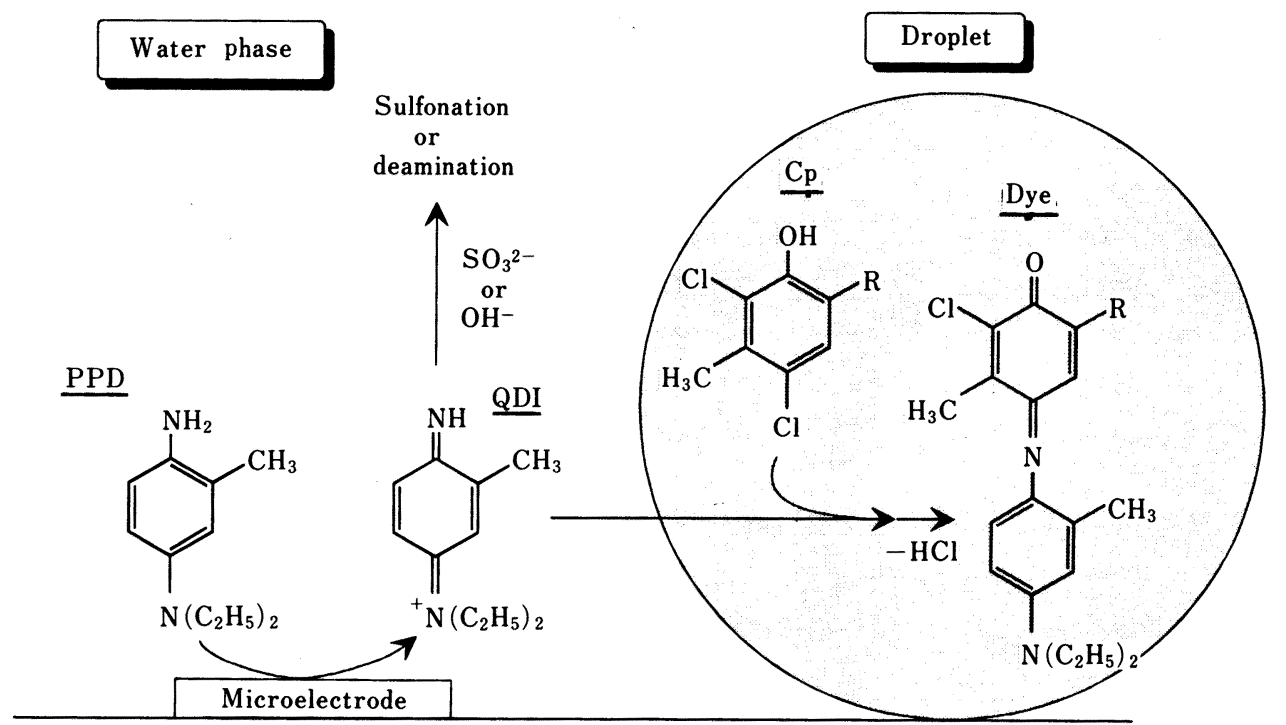

Fig. 5 General reaction scheme of dye formation reactions in the oil/water emulsion system

粒子内部の任意の位置のスペクトル情報を得ることが可 能である．以下に実際の測定例を述べる.

\section{3 水に分散した油滴 1 粒の吸収スペクトル測定}

水中に分散した油滴は液一液抽出だけではなく，日常 生活における食品, 化粧品, 医薬品, 塗料など広い分野 で重要な役割を果たしている．油滴内の物質，あるいは 水相の物質は油水界面により互いに分離されているが, この界面を通して物質移動や反応が起こる. 又, 目的・ 用途に応じて様々な粒径の油滴が利用されている. 直径 $10 \mu \mathrm{m}$ ではその体積は $0.5 \mathrm{pl}$ 程度しかなく, 油滴を非常 に小さな容器・反応場と考えることができる.ここで は, レーザー捕そく・顕微分光法を用い, カラー写真の 発色過程をモデルとした油水界面反応を解析した例, 並 びにカラー写真用色素を含む油滴の融合について紹介す る.

\section{3・1 油滴内の色素生成過程の直接観測 ${ }^{21)}$}

カラーフィルムには, 感光性の異なる 3 種類の乳剂 層が重ねて塗られている.これらは青感層, 緑感層, 及 び赤感層であり，それぞれイエロー，マゼンタ及びシア ンに発色する色素前駆体（カプラー, Cp）と, 感光体 であるハロゲン化銀の混合エマルションからなる. 露光 されたハロゲン化銀は現像過程において現像薬を酸化 し, この酸化された現像薬が $\mathrm{Cp}$ と反応し色素となり発
色する ${ }^{23)}$.ここでは, シアン色素の発色過程をモデル とし, 現像薬を酸化するために, 露光されたハロゲン化 銀の代わりにマイクロ電極を用いている.

Fig. 5 に示すように，サファイア基板上に作製したマ イクロ金電極（幅 $9 \mu \mathrm{m}$, 長さ $100 \mu \mathrm{m}$, 厚さ $0.3 \mu \mathrm{m}$ ） を用いて, 水相中で現像薬である $p$-フェニレンジアミ ン（PPD）を酸化しキノンジイミン（QDI）とする. QDI は水相中を拡散し, 油滴に達すると油滴内の $\mathrm{Cp}$ と反応し色素を生成する. 水相中には QDI の拡散距離 とその寿命を制御するために, 亜硫酸イオンと水酸化物 イオンが加えられている. それらの濃度が高いと QDI は水相中の副反応により速やかに消費されるため拡散距 離は短くなり, Cp との反応効率（従って感度）は低下 する. 高い反応効率を達成するためには, イオン濃度だ けではなく, PPD を酸化する位置（電極）と油滴の距 離を最適化する必要がある. そこで,レーザー捕そく法 により油滴 1 粒を捕そくし, マイク口電極と油滴の距 離を制御しながら PPD を酸化し, 油滴内の色素の生成 を吸収スペクトル測定により追跡した.

油滴 1 粒をマイクロ電極近傍に捕そく・配置した様 子を Fig. 6 に示す. 油滴一電極間距離は捕そく用レー ザー光の焦点位置を $x-y$ 平面内で変えることにより, 自 由に変化させることができる.この状態で水相中の PPD を定電位電解 $(+100 \mathrm{mV} v s . \mathrm{Ag} / \mathrm{AgCl})$ すると, 初 め無色であった油滴はシアン色を発し, 色素生成が確認 


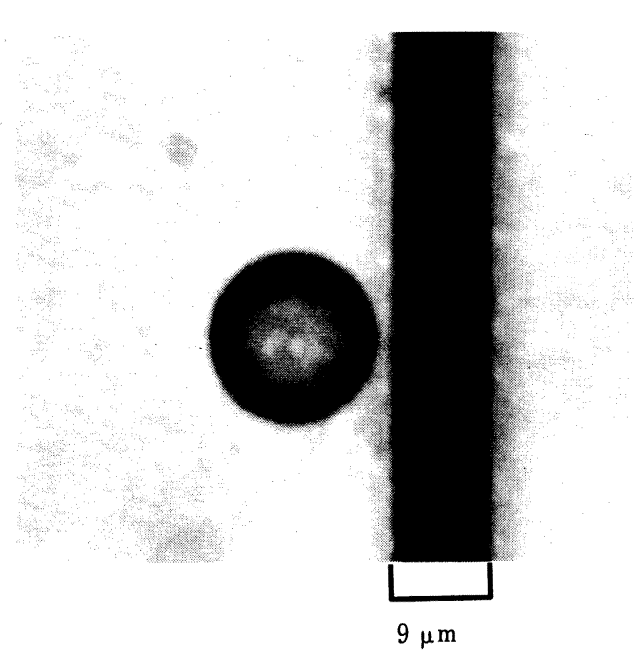

Au microelectrode

Fig. 6 Laser trapping of a single dibutylphtalate droplet $\{$ diameter $(d)=14.7 \mu \mathrm{m}\}$ containing $\mathrm{Cp}$ in the vicinity of the Au microelectrode

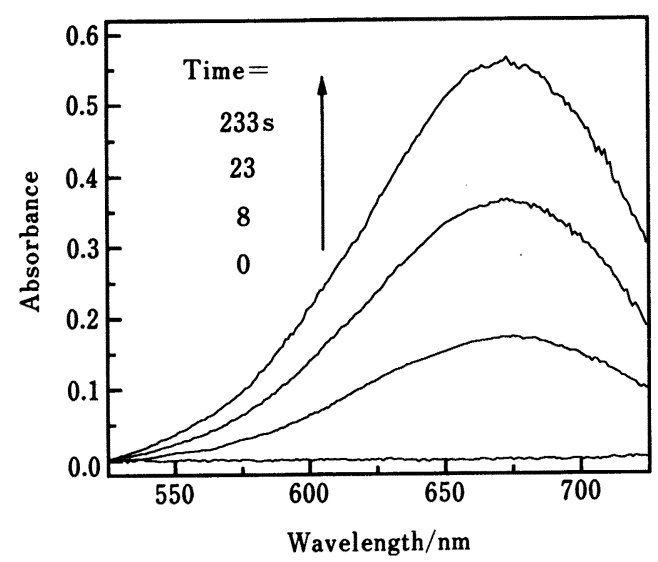

Fig. 7 Absorption spectra of a single laser-trapped droplet $(d=10.5 \mu \mathrm{m})$ during electrolysis of PPD in the water phase: $[\mathrm{Cp}]=0.03 \mathrm{~mol} \mathrm{dm}^{-3}, \quad[\mathrm{PPD}]$ $=5 \times 10^{-3} \mathrm{~mol} \mathrm{dm}^{-3}, \mathrm{pH}=10$

された。このときの油滴 1 粒の吸収スペクトルの経時 変化を Fig. 7 に示す. 電解を始めると $670 \mathrm{~nm}$ 付近に 極大波長を有する吸収バンドの強度が大きくなり, 100 200 秒程度で飽和するのが観測された.この吸収 スペクトルは別途調製したシアン色素の吸収スペクトル と一致し, そのモル吸光係数をもとに微小油滴内に生成 した色素濃度を決定することができた．更に，QDIの

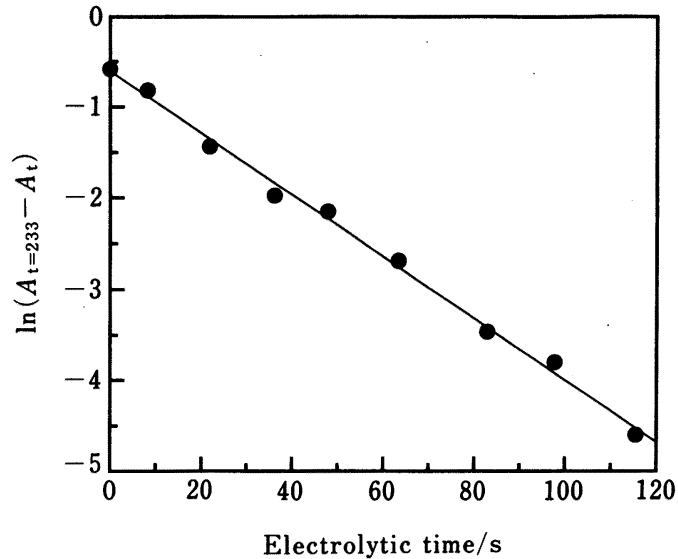

Fig. 8 Pseudo-first order plot for the dye formation reaction in the laser-trapped droplet

供給量が時間によらず一定であると考えられることか ら, この色素生成反応は擬一次反応として解析すること ができる. 実際, Fig. 8 に示したようなプロットが得ら れ, その傾きより反応速度を求めることができた. 油滴電極間距離が大きくなると反応速度は急激に低下し, 単 一油滴ごとの色素生成効率を空間的に制御することがで きる. 事実, 反応速度の変化とシミュレーションによっ て得られる電極周辺での QDI 濃度分布とを対応付ける ことに成功している.

レーザー捕そく・顕微分光法とマイクロ電極を組み合 わせることにより, 油滴 1 粒ごとの色素生成過程のダ イナミックスを初めて調べることができた，更に，油滴 と電極の空間配置を制御することにより，その反応速度 の電極-油滴間距離依存性を議論することが可能となっ た.

\section{$3 \cdot 2$ 液滴の融合}

先にも述べたように，マイクロメートルサイズの液滴 は pl サイズの小さな容器と考えることができる. 又, その容器は油水界面によって分散媒と隔離されているだ けなので, 異なる物質を含む二つの液滴を接触させるこ とにより液滴を融合し，反応を誘起することができると 考えられる. 更に次々に液滴を融合させていくことによ り，単一液滴に基づいた極微小量の滴定システムを構築 することができる．又，このような極微小サイズの空間 では拡散による混合は非常に早く進むと考えられるた め, 融合後の経時変化を追跡することにより反応機構の 動的解析が可能になるものと考えられる. 以上のことを 


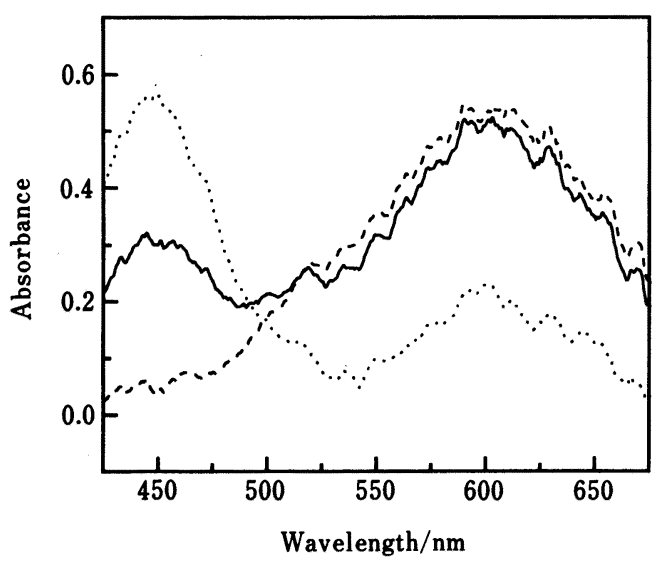

Fig. 9 Absorption spectra of individual droplets containing y-dye $\left(---; 20.8 \mu \mathrm{m}, 0.02 \mathrm{~mol} \mathrm{dm}^{-3}\right)$ and c-dye $\left(--; 26.0 \mu \mathrm{m}, 0.04 \mathrm{~mol} \mathrm{dm}^{-3}\right)$ before droplet fusion

Absorption spectrum after fusion of the two droplets $(-, 29.4 \mu \mathrm{m})$.

踏まえて, レーザー捕そく・顕微分光法による液滴の融 合を試みた ${ }^{24)}$.

二つの液滴を同時かつ独立にマニピュレートするため に，捕そく用レーザー光を二つに分けて顕微鏡に導入し た. 二つのレーザー光は干渉しないように，その偏光面 を互いに直交させている. カラ一写真で用いられるイエ ロー，及びシアン色素（y-Dye, c-Dye）を含むジブチ ルフタレート溶液をそれぞれ水に分散・混合し試料とし た. y-Dye, c-Dye を含む油滴を 2 本のレーザー光によ り別々に捕そくした後, 2 本のレーザ一光を徐々に近付 け，二つの油滴を接触させる．更にレーザー光の焦点を 一致させると二つの油滴は融合し, 瞬時に一つの大き な緑色の油滴となった。この様子は, 顕微鏡に取りつけ た CCD カメラにより観察できるとともに, 吸収スペク トル測定によって追跡することができる（Fig. 9). 初 め, y-Dye, c-Dye は 450, $600 \mathrm{~nm}$ にそれぞれ吸収極 大を持つ.この二つの油滴を融合すると, 二つのスペク トルを足し合わせたスペクトル (図の実線) が得られ, 油滴の融合により油滴内の色素が混合することが確認で きた。

更にこの方法を発展させ，スペクトル測定や電気化学 測定を同時に行うことにより，単一液滴に基づいた極微 小量の滴定への応用や, 反応の動的解析へ応用できるも のと期待している.

$$
4 \text { マイクロカプセル }
$$

内部に様々な物質を内包することのできるマイクロカ プセルは，医薬におけるドラッグデリバリーシステムを 始めとして広範な分野において応用・研究されている. 前述の液滴系では油水界面を通して物質移動, 反応が起 こるのに対し, マイクロカプセルの場合には界面は高分 子膜であるため, カプセル内外での物質移動・反応は液 滴系に比べ十分遅くなると考えられる.これを利用し， マイクロカプセルを構成する膜により内包物質を外部環 境より保護したり, 膜の特性を利用し膜内外の物質移動 を制御するなど，内包物質を目的の場で効率的に放出さ せることも可能と考えられる.

応用面から考えると, 内包物質のマイクロカプセル内 の状態よりも, 膜外への内包物質の徐放に関する研究に 関心が向けられている. そのため, 外液に関する測定は 様々行われている. 一方, マイクロカプセルそのものを 対象とした測定は, その大きさや形状, 分散性, 安定性 といった物理的性質の測定が中心である. 界面重合法で 作製されたマイクロカプセルは, 目的の内包物質だけで なく, 膜を作るためのモノマーや重合開始剤, 界面活性 剤, 安定剤などが組み合わされた複雑な系となってい る. 従って, マイクロカプセルの調製条件により, 系に 含まれる種々の試薬間の相互作用を通して内包物質の 濃度やカプセル内での分布状態変化を及ぼすことが予想 される.レーザー捕そく・顕微分光法を用いることによ り, マイクロカプセル 1 粒ずつを分光測定できるため, これまでに得られなかったマイクロカプセルそのものに 関する情報を直接得ることができる.

ここでは, 色素を内包する単一マイクロカプセルの蛍 光・吸収測定によるマイクロカプセル内での色素の濃 度・分布状態を明らかにした例を紹介する.

\section{4・1 マイクロカプセル中のピレン蛍光 ${ }^{25)}$}

Koshioka らは, ピレンのエキシマー生成を利用して, マイクロカプセルごとのピレン濃度について検討した結 果を報告している. ピレンートルエン溶液を内包したメ ラミン樹脂マイクロカプセルを調製し, 共焦点型顕微鏡 を用いてその 1 粒ずつの蛍光スペクトルが測定された (Fig. 10). 希薄溶液中では, ピレンは $370 \sim 400 \mathrm{~nm}$ 付 近に振動構造を有するシャープなモノマー発光を示す. 濃度が高くなるにつれて $470 \mathrm{~nm}$ 付近にブロードな新た な発光バンドが現れる．これは励起状態と基底状態のピ レン 2 分子で形成される励起二量体からの発光で, エ キシマー発光と呼ばれる. エキシマー発光とモノマー発 


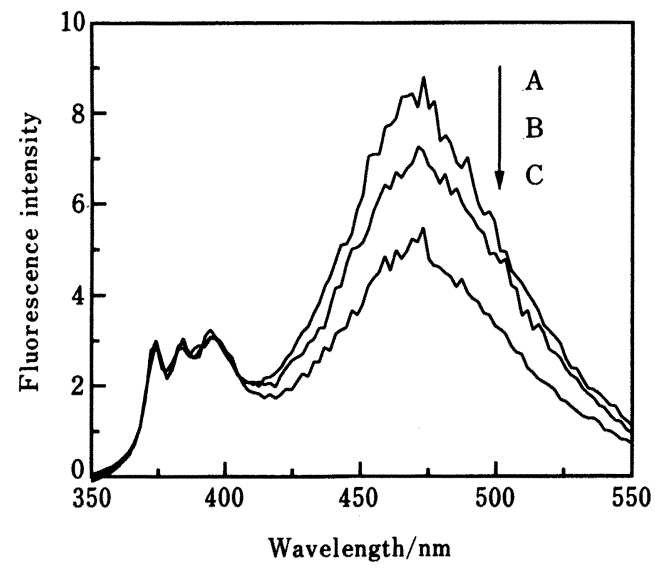

Fig. 10 Fluorescence spectra of single microcapsules containing pyrene where the intensities are normalized at the monomer band

The diameters of the capsules A, B, and C are 19.2, 6.5 , and $6.8 \mu \mathrm{m}$, respectively. The data were taken from ref. 25.

光の相対強度比 $\left(I_{\mathrm{E}} / I_{\mathrm{M}}\right)$ は, ピレン濃度に依存するだ けでなく，媒体の粘度などピレン周囲のミクロ環境にも 強く依存するため, 蛍光プローブとして様々な系で利用 されている26).

Fig. 10 には, 同濃度のピレンートルエン溶液を内包す る, 粒径の異なるマイクロカプセルの蛍光スペクトルを 示した. 各々のスペクトル強度はモノマー蛍光強度で規 格化しており, エキシマーの相対強度がカプセルごとに 異なることが明らかである. カプセルごとにエキシマー 生成効率が異なる理由として, Koshioka らはエキシ マー形成が二分子反応であるため, カプセルごとにピレ ン濃度, あるいはトルエン相中のピレンの拡散定数が異 なるものと推論した.

拡散定数の違いが原因であると考えると, マイクロカ プセルごとにトルエンの粘性が異なるはずである.つま り, マイクロカプセルが小さくなるほど, 膜の影響を受 けやすくなり，粘性が高くなるものと考えられる．この 場合, エキシマー生成の速度定数が変化することにな る. そこで, マイクロカプセル 1 粒ごとの時間分解蛍 光測定により, モノマー発光の減衰曲線, 及びエキシ マ一発光の生成・減衰曲線を詳しく解析し, エキシマー 生成の速度定数を求める試みも併せて行われた。 その結 果, 各速度定数はマイクロカプセルごとに変わらず, 粒 径依存性も見られなかった。このことは, マイクロカプ セル内のトルエンの粘性, 又はピレンの微視的環境は,

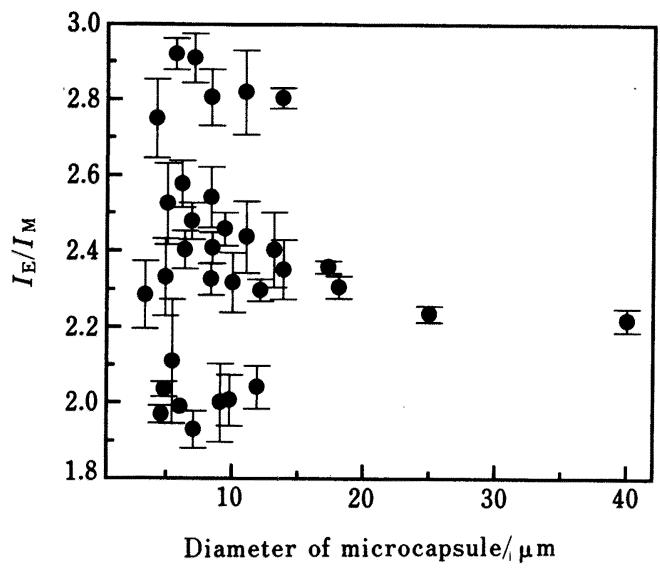

Fig. 11 Capsule diameter dependence of $I_{E} / I_{M}$ The data were taken from ref. 25 .

バルクのトルエン母液中とほぼ同じであることを示す． 従って， $I_{\mathrm{E}} / I_{\mathrm{M}}$ がマイクロカプセルごとに異なるのは， ピレン濃度が異なるためと結論された。

様々な粒径のマイクロカプセルについての $I_{\mathrm{E}} / I_{\mathrm{M}}$ の 粒径依存性を Fig. 11 にまとめた。粒径に対する明確な 依存性は見られないが，粒径が $20 \mu \mathrm{m}$ 以下ではその值 はばらつき， $20 \mu \mathrm{m}$ 以上ではほぼ一定の值となった。こ の值は母夜のそれとほぼ一致し，大きなマイクロカプセ ルの内液はバルクの母液にほぼ等しいと考えてよいが, 小さなマイクロカプセル中では粒ごとに濃度がばらつく ことが示された。

マイクロカプセルは水中にトルエンを激しくかき混ぜ て分散させ，その界面でモノマーを重合させて調製す る. カプセルごとにピレン濃度が異なる理由の一つとし て, ピレンは水に不溶であるため, トルエンと水が混じ ることにより析出することが考えられる．析出が起こる と, 液滴間でピレン濃度が変化し, 非平衡状態が作り出 される.この液滴間の濃度の違いは, ピレンの分配・再 平衡過程により解消される方向に向かう。しかし，一部 の液滴では界面でメラミンの重合が進み, 高分子膜が生 成する，又，液滴が融合することも考えられる．大きい カプセルの場合, 融合により平均化が進み, バルクの濃 度に近付くであろう. 一方, 小さなカプセルでは, 生じ た濃度の不均一が解消されないままカプセルに閉じ込め られる. 各カプセルごとにピレン濃度がばらつくのは， このような理由によるものと Koshioka らは説明してい る.

3 節で述べた液滴の系においては，分散時に仮に濃度 
分布が生じたとしても油水界面を経由した物質移動を通 して, 速やかに解消される. マイクロカプセルでは高分 子膜を通過した物質移動が要求されるため, カプセル生 成後の非平衡状態が長時間保たれることが示唆された。

\section{$4 \cdot 2$ 色素を内包するマイクロカプセルの吸収スペク トル}

先のピレンのエキシマー生成では濃度だけではなく, 反応の動的過程も関与するため複雑な解析を必要とす る. 従って, 吸収測定によりマイクロカプセル内の濃度 を直接決定することが望まれる. そこで, トルエンへの 溶解性が高く, かつ水相への分配係数が小さい, 幾つか の色素を内包するメラミン樹脂マイクロカプセルを調製 し, その 1 粒ごとの吸収スペクトルから色素濃度の粒 径依存性を検討した。微粒子の吸収スペクトル測定で は, プローブ光は微粒子の中心を通る. 従って, 微粒子 の粒径が光路長となるため, 色素濃度がカプセルごとに 等しい場合には, 吸光度と粒径のプロットは原点を通る 直線となり，その傾きからモル吸光係数が得られるはず である。

例として, ディスパースオレンジ 13 (DO 13), 及び 亜鉛テトラフェニルポルフィリン $(\mathrm{Zn}$ TPP $)$ のトルエ ン溶液を内包するマイクロカプセルの吸収スペクトルを Fig. 12 に示す. いずれの吸収スペクトルも，その形状 及び吸収極大波長はトルエン均一溶液中のものと一致し た.しかし, 吸光度の粒径依存性は両者で全く異なっ た.

DO 13 の場合, 吸光度はマイクロカプセルの粒径に 比例して大きくなり，その結果得られたモル吸光係数 は, トルエン均一溶液中で得られた值と一致した。先の ピレンについて得られた結果と異なり，DO 13 ではカ プセルごとに濃度が変わらず, 調製時の母液濃度のまま マイクロカプセルが調製されたと結論される。一方, Zn TPP を内包したマイクロカプセルでは, ピレンで見 られたような濃度のばらつきは観測されない.しかし， 10～50 $\mu \mathrm{m}$ の粒径で吸光度が粒径に依存せずほとんど一 定の值を示すとともに，調製時の母液濃度より計算され る吸光度よりも低い值を示した。この結果は, Zn TPP が内包液中で均一に分布するのではなく, マイクロカプ セル調製時に膜を構成するメラミン樹脂膜内に吸着・取 り込まれると考えることにより説明される27).

通常, マイクロカプセル内の内包物質濃度は, カプセ ル調製時の母液濃度を基に考えられている. 又, 内包物 質は均一に存在するものと仮定している. しかし, ここ に示したように同じメラミン樹脂マイクロカプセルを同

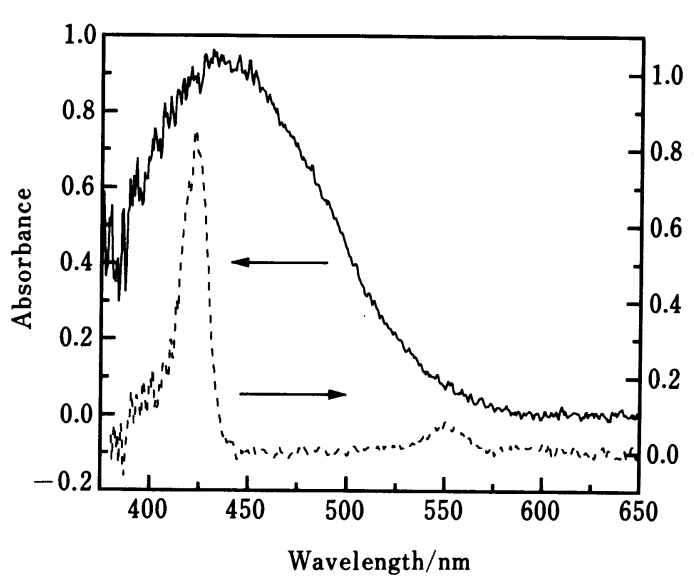

Fig. 12 Absorption spectrum of a single microcapsule containing DO $13\left(-; 0.01 \mathrm{~mol} \mathrm{dm}^{-3}\right)$ and ZnTPP (---; $\left.2 \times 10^{-3} \mathrm{~mol} \mathrm{dm}^{-3}\right)$

じ条件で調製しても, 内包物質の性質により, 均一分布 となったり, 樹脂膜内に取り込まれたり, あるいは粒ご とで濃度が異なることが実験的に確かめられた。これ は, 従来のようにマイクロカプセルの外液のみの分析で は必ずしも正しい結果を与えるものでないことを意味し ており, 1 粒ごとの分光測定が極めて重要かつ不可欠で あることを示すものである.

\section{5 色素を吸着したイオン交換樹脂の分光測定}

分析化学においてはなじみ深いイオン交換樹脂, キ レート樹脂などの固体微粒子に, 顕微分光法を応用した 例を紹介する，溶液に分散させた固体微粒子では, 固液界面の性質が重要である. 更に, 先の 2 例では微粒 子内部が液体であったのに対し, 微粒子固体内部への物 質移動は極めて遅くなる．クロマトグラフィーの例を出 すまでもなく, 種々のタイプの吸着能を有する固体微粒 子は多方面にわたって広く利用されているが, 微粒子表 面の設計とともに, 大きさ, 表面積を大きくするための ミクロポアサイズの制御等, 盛んに研究されている.こ こでは, 固体微粒子としてイオン交換樹脂を用い, 色素 イオンの吸着・樹脂内部への浸透過程について, 樹脂 1 粒ごとの吸収スペクトル測定, 及び共焦点レーザー顕微 鏡による三次元空間分解発光測定から検討した例につい て述べる.

\section{$5 \cdot 1$ 樹脂 1 粒ごとの吸収スペクトル}

樹脂として, 粒径 17 20 $\mu \mathrm{m}$ の陽イオン交換樹脂

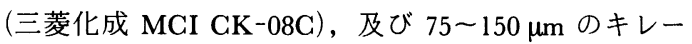




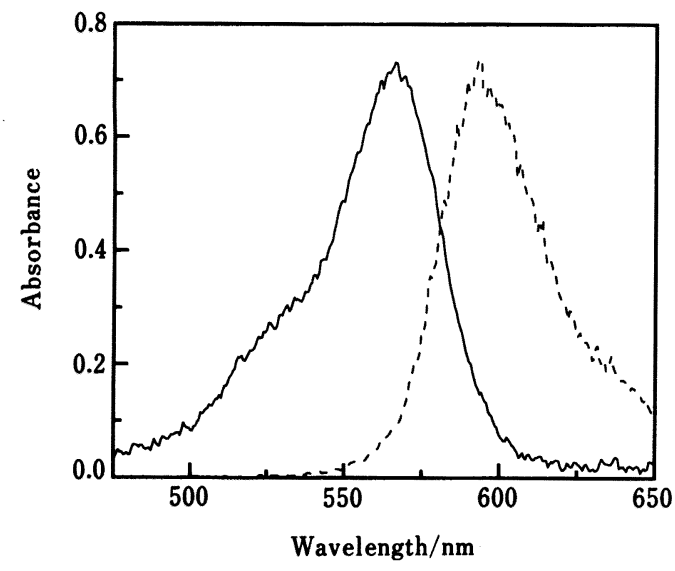

Fig. 13 Absorption ( - ) and emission (-- ) spectra of $\mathrm{RhB}$ adsorbed on a single MCI resin particle

ト樹脂（BioRad Chelex 100）を用いた. 所定濃度 $\left(10^{-9} \sim 10^{-7} \mathrm{~mol} \mathrm{dm}^{-3}\right)$ に調製した色素水溶液の一定 量に樹脂を投入し, 一定時間浸した後, その 1 粒の吸 収スペクトルを測定した。

陽イオン性色素であるローダミンB（RhB，モル吸光 係数 $=1.1 \times 10^{5} \mathrm{~mol}^{-1} \mathrm{dm}^{3} \mathrm{~cm}^{-1}$ at $\left.554 \mathrm{~nm}\right)$ を $3 \times 10^{-7}$ $\mathrm{mol} \mathrm{dm}{ }^{-3}$ の水溶液から $20.4 \mu \mathrm{m}$ の MCI 樹脂に吸着さ せたときの吸収・発光スペクトルを Fig. 13 に示す. 通 常の $1 \mathrm{~cm}$ のキュベットを使う吸光測定に比べ, 光路長 (樹脂直径) は $1 / 500$ となっているにもかかわらず 0.7 程度の吸光度が得られた。これは, 希薄溶液中の RhB が樹脂に吸着・濃縮された, いわゆる固相濃縮の結果で ある. この吸光度を基に, $\mathrm{RhB}$ が樹脂内で均一に分布 していると仮定して（この仮定は後述するように正しく ないがおおよその值を表している), 樹脂内の RhB 濃 度を計算すると $3 \times 10^{-3} \mathrm{~mol} \mathrm{dm}{ }^{-3}$ 程度となる. 母液に 比べ $10^{4}$ 程度に濃縮されていることが分かる. 又, 樹 脂 1 粒の体積が約 $4 \mathrm{pl}$ であることを考えると, およそ $10^{-14} \mathrm{~mol}$ 程度の色素を検出したことになる. 更に, 吸 光度が母液の濃度に比例して直線的に増加することが確 かめられた，濃縮率を高めるために吸着条件の最適化を 図れば, 樹脂 1 粒を基にした固相濃縮・分析への応用 が十分可能であることが分かった ${ }^{28)}$.

$\mathrm{RhB}$ は水溶液中では, $10^{-4} \mathrm{~mol} \mathrm{dm}^{-3}$ 以上の濃度で二 量体を形成し, $525 \mathrm{~nm}$ 付近の吸収バンドが大きくなる ことが知られている29). しかし，Fig. 13 に示したよう に樹脂内で RhB は母液に比べて高濃度で存在するにも かかわらず, 吸収スペクトルの形状は, 希薄水溶液中の

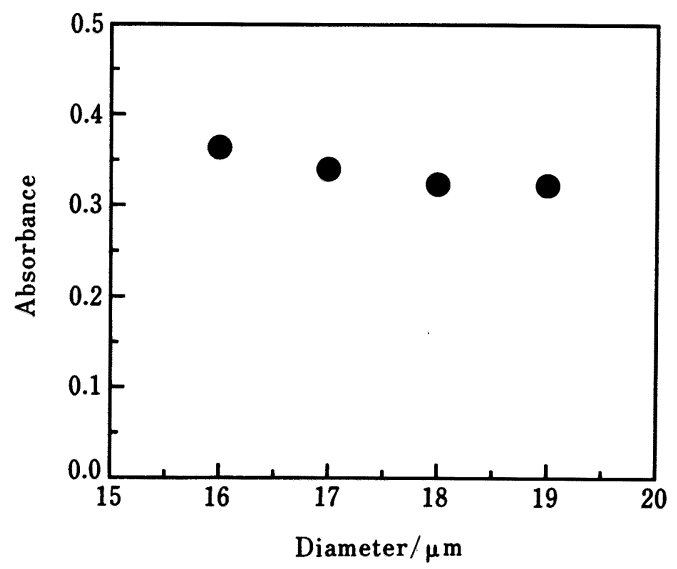

Fig. 14 Particle diameter dependence of $\mathrm{RhB}$ absorbance

ものと一致し, 樹脂内に吸着しても大きな変化はなかっ た.これは $\mathrm{RhB}$ が樹脂内のイオン交換基に吸着される ため, RhB 分子が互いに近付くことができず孤立化し ており，二量体を形成しにくくなっているものと考えら れる，樹脂に吸着させることにより，色素分子間の相互 作用を制御することができることが，1 粒の吸収スペク トル測定により確認することができた.

\section{$5 \cdot 2$ 吸光度の樹脂粒径依存性}

同一条件下で粒径の異なる樹脂に色素を吸着させ，そ の 1 粒ごとの吸光度を求めた. MCI 樹脂に RhB を吸 着させた場合，粒径範囲は狭いが Fig. 14 に示すように 吸光度の粒径依存性は見られなかった．より広い粒度分 布を持つChelex 樹脂について異なる構造を持つ色素を 吸着させた場合でも, 吸光度が樹脂粒径に依存せずほと んど一定であった ${ }^{20)}$.

一般的に, 吸着 (分配) 平衡は吸着剤と溶媒の量比に 関連して考えられており, 個々の吸着剤の大きさや, 樹 脂中における溶質の分布は考慮されていない，樹脂の粒 径が異なっていても樹脂内の色素濃度が一定で, かつ色 素が均一に分布しているならば，樹脂 1 粒ごとの吸光 度は粒径依存性を示し, 粒径, すなわち光路長に比例し て大きくなるはずである，従って，Fig. 14 の結果は粒 ごとに濃度が異なるか, あるいは色素が樹脂内で均一に 分布しておらず表面層にのみ吸着しているかのどちらか を示唆するものである. 母液濃度に比例して吸光度が大 きくなることより前者は考えにくく，表面層のみに色素 が吸着していることが考えられる. そこで, 三次元空間 分解能を有する共焦点レーザー顕微鏡による蛍光測定を 


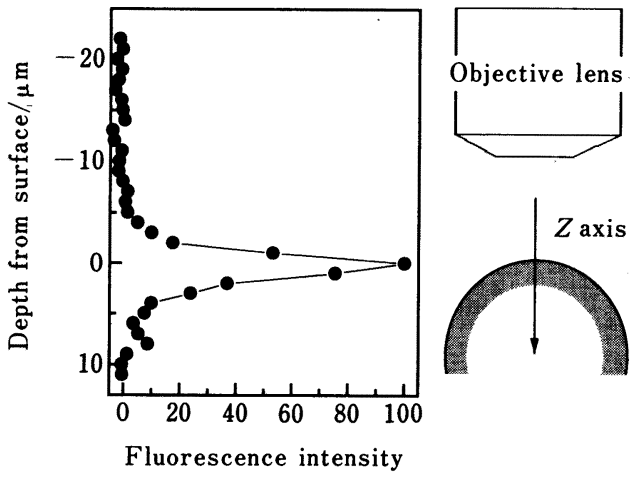

Fig. 15 Fluorescence intensity profile of $\mathrm{RhB}$ in a MCI resin particle $(d=20 \mu \mathrm{m})$

Depth values 0 and $10 \mu \mathrm{m}$ represent the surface and center of the particle, respectively.

行い，樹脂内での色素の分布状態を調べた.

\section{5 ・3 共焦点レーザー顥微鏡による空間分解蛍光測定}

$2 \cdot 3$ で述べたように共焦点顕微鏡を用いることによ り, 樹脂内部での色素の濃度分布を蛍光強度の $z$ 軸プ ロフィルとして直接測定することができる(本研究で用 いたシステムの $z$ 軸分解能は約 $\left.0.5 \mu \mathrm{m}^{19)}\right)$. そこで, $\mathrm{RhB}$ 水溶液 $\left(3.4 \times 10^{-8} \mathrm{~mol} \mathrm{dm}^{-3}\right)$ に MCI 樹脂（粒径 $20 \mu \mathrm{m})$ を投入し，一定時間浸した後測定を行った。2 時間浸した後の結果を Fig. 15 に示す. 図の縦軸は, 樹 脂の表面を原点（深さ $=0 ）$ とし，樹脂の中心を梁 さ $=10 \mu \mathrm{m}$ として表示した.

励起光の焦点を樹脂の外側に合わせた場合には全く蛍 光が観測されない. 励起光の焦点を樹脂の表面近傍とし たとき初めて蛍光が観測され，焦点が樹脂の表面よりや や内側付近で蛍光強度は最大となる. 更に焦点を樹脂内 部に走查すると蛍光強度は減少し，樹脂の中心付近では 再び蛍光が観測されなくなる。蛍光強度は RhB の濃度 に対応する. 従って, Fig. 15 のピークの半值幅より 2 時間の浸せきでは $\mathrm{RhB}$ は樹脂の表面から約 $3 \mu \mathrm{m}$ の層 のみに存在しており, 樹脂の内部までは拡散・浸透して いないことが確かめられた。吸光度が粒径依存しない理 由として考えた表面吸着を支持する結果が得られた ${ }^{28)}$.

樹脂の浸す時間を長くするにつれて, 蛍光が観測され る層は厚くなり，樹脂の内部からも蛍光が観測されるよ うになる。ほぼ平らな蛍光プロフィル，すなわち樹脂内 に RhB が均一に分布するためには, 約 1 週間程度必要 であった。この結果は，まず樹脂の表面層でのみ色素の 四着が起こり, その後ゆっくりと樹脂内部に色素が拡
散・浸透していくことを示している. イオン交換過程 は，境膜拡散，粒子内拡散，及びイオン交換点でのイオ ン交換反応の三つの過程で解析される7). 本実験では共 焦点レーザー顕微鏡を用いることによりこの粒子内拡散 過程を直接観測することができた，更に，この蛍光プロ フィルの経時変化を基に，球状拡散モデルによりシミュ レーションを行うことにより, $\mathrm{RhB}$ の樹脂内の拡散係 数を求めることもできる ${ }^{30)}$.

\section{6 結 言}

以上述べてきたように, レーザー捕そく・顕微分光法 を用いた微粒子 1 粒ごとの分光分析により, 微粒子分 散系や集合系を対象とした空間分解しない測定では得る ことのできない，微粒子 1 粒ごとの化学の特性を明ら かにすることができることを示した．これらの方法論を 更に発展・展開させることにより，微粒子にかかわるク ロマトグラフィーや液-液抽出といった分析化学の基本 過程の微視的機構の解明だけではなく, 微小領域で起こ る様々な現象の探索・解明に役立つものと考えている. 更に，複数のレーザー光を用いて複数の微粒子を任意の 位置に配置することや，マイクロ電極を組み合わせるこ とにより，化学反応や現象を三次元空間において任意に 制御したり分析する方法論が，今後大いに発展すること を期待している.

\section{文献}

1) S. Hamai, N. Tamai, H. Masuhara: Chem. Lett., 1993, 1105.

2) M. Yanagimachi, N. Tamai, H. Masuhara: Chem. Phys. Lett., 201, 115 (1993).

3) M. Yanagimachi, N. Tamai, H. Masuhara: Chem. Phys. Lett., 200, 469 (1992).

4) J. M. Lantz, R. M. Corn: J. Phys. Chem., 98, 4899 (1994)

5) Z. Samec, T. Kakiuchi: "Advances in Electroschemistry and Electroschemical Science", Vol. 4, Edited by H. Gerischer, C. W. Tobias, (1995), (VCH, Weinheim)

6) G. D. Christian: "Analytical Chemistry", 4th edition, (1986), (J. Wiley \& Sons, New York).

7) F. Helfferich: "Ion Exchange", (1962), (McGrawhill, New York).

8) O. Samuelson: "Ion Exchange Separations in Analytical Chemistry", (1963), (John Wiley \& Sons, New York).

9) G. Kortüm: "Reflectance Spectroscopy-Principles, Methods, Applications", (1969), (Splinger-Verlag, Berlin)

10) K. Ohzeki, M. Minorilawa, F. Yokota, I. Nukatsuka, R. Ishida: Analyst (London), 115, 23 (1990). 
11) K. Nakatani, K. Chikama, H.-B. Kim, N. Kitamura: Chem. Phys. Lett., 237, 133 (1995).

12) M. Ueda, H.-B. Kim, K. Ichimura: J. Mater. Chem., 4, 883 (1994).

13) H.-B. Kim, M. A. Winnik: Macromolecules, 28, 2033 (1995).

14）増原極微変換プロジェクト編: “マイクロ化学”, (1993)，(化学同人).

15) H. Masuhara, F. C. DeSchryver, N. Kitamura, N. Tamai (Eds.): "Microchemistry-Spectroscopy and Chemistry in Small Domains", (1994), (Elsevier, Amsterdam).

16) N. Kitamura, K. Nakatani, H.-B. Kim: Pure \& Appl. Chem., 67, 79 (1995).

17) A. Ashkin, J. M. Dziedzic: Opt. Lett., 11, 288 (1986).

18）斉藤 究，柳田敏雄: 蛋白質核酸酵素, 39, 1344 (1994).

19) K. Sasaki, M. Koshioka, H. Misawa, N. Kitamura, H. Masuhara: Appl. Phys. Lett., 60, 807 (1992).

20）金 幸夫，林 昌彦，中谷清治，喜多村 曻：日 本化学会第 67 春季年会講演要旨集, $1 \mathrm{M} 225$ (1994).

21) K. Nakatani, T. Suto, M. Wakabayashi, H.-B.
Kim, N. Kitamura: J. Phys. Chem., 99, 4745 (1995).

22) T. Wilson (Ed.): "Confocal Microscopy", (1990), (Academic Press, London).

23) T. H. James: "The Theory of the Photographic Process", (1977), (Macmillian, New York).

24）八尾浩史, 井上晴久, 中谷清治, 金 幸夫, 喜多 村 曻: 日本分析化学会第 43 年会講演要旨集, p. 95 (1994).

25) M. Koshioka, H. Misawa, K. Sasaki, N. Kitamura, H. Masuhara: J. Phys. Chem., 96, 2909 (1992).

26) J. B. Birks: "Photophysics of Aromatic Molecules", (1970), (John Wiley \& Sons, London).

27）三浦篤志，金幸夫，喜多村㷠：北海道支部 1995 年冬期研究発表会講演要旨集, p. 131 (1995).

28) H.-B. Kim, M. Hayashi, K. Nakatani, N. Kitamura: Abstracts of XVth IUPAC Symposium on Photochemistry, D71 (1994), Prague.

29) J. E. Selwyn, J. I. Steinfeld: J. Phys. Chem., 76, 762 (1972).

30）金幸夫，林 昌彦，喜多村曻：日本化学会第 69 春季年会講演要旨集, 1C204 (1995).

Laser trapping-microspectroscopy of single microparticles. Haeng-Boo KIM, Kiyoharu Nakatani, Hiroshi YaO and Noboru Kitamura (Division of Chemistry, Graduate School of Science, Hokkaido University, Kita-10, Nishi-8, Kita-ku, Sapporo-shi, Hokkaido 060)

As the surface area/volume ratio of a particle increases with decreasing particle diameter, interfacial phenomena such as mass transfer, adsorption/desorption, and distribution of analytes at the solution/particle boundary become strongly dependent on the particle size. Here we describe a laser trapping-microspectroscopy technique applicable to spectroscopic measurements of single microparticles in solution and demonstrate the importance of spatially-resolved measurements to investigate heterogeneous chemical systems.

(Received July 21, 1995)

\section{Keywords}

droplet; microcapsule; ion-exchange resin; laser trapping-microspectroscopy; size dependence. 